\title{
Phytochemical Characterization, In Vitro Antioxidant, Cytotoxic, and Antibacterial Effects of Aristolochia longa L.,
}

\author{
Amina El Yahyaoui El Idrissi ${ }^{1}$, Aya Khouchlaa ${ }^{1, *(D)}$, Abdelhakim Bouyahya ${ }^{1}$ (D), Youssef Bakri, M'hamed \\ Tijane ${ }^{1}$ \\ 1 Laboratory of Human Pathologies Biology, Faculty of Science, Genomic Center of Human Pathologies, Faculty of \\ Medicine and Pharmacy, Mohammed V University in Rabat, Morocco \\ * Correspondence: aya.khouchlaa@gmail.com;
}

Scopus Author ID 57191631959

Received: 24.06.2020; Revised: 13.07.2020; Accepted: 14.07.2020; Published: 18.07.2020

\begin{abstract}
The aim of this study was devoted, in the one hand, to determine a preliminary phytochemical screening of methanolic and aqueous root extracts of Aristolochia longa L. In the other hand, polyphenols and flavonoids contents, in vitro antioxidant, antitumor, and antibacterial activities of the organic extract of A. longa were determined. Phytochemical screening was carried out using standard methods of precipitation and coloration reactions. The total phenol content and flavonoid contents were determined using the Folin-Ciocalteu method and Aluminum chloride colorimetric method, respectively. Antioxidant activity was studied using DPPH assay. The cytotoxic activity of extracts was evaluated against three cancerous cell lines using MTT assay, and antibacterial activity was tested against Escherichia coli, Pseudomonas aeruginosa, Rhodococcus equi, and Staphylococcus aureus using the agar well diffusion assay. Preliminary phytochemical screening for aqueous and ethanolic extracts revealed the presence of starch, tannins, flavonoids, coumarins, and anthocyanins. The total phenol content of $A$. longa extracts showed that the methanol extract has the highest polyphenol and flavonoid concentrations with $101.4 \mathrm{mg} \mathrm{GAE}$ (Gallic acid equivalent)/g and $54.21 \mathrm{mg}$ QE (Quercetin equivalent)/g extract, respectively. The methanolic extract also exhibited the highest antioxidant capacity of DPPH $\left(\mathrm{IC}_{50}=1.32 \mathrm{mg} / \mathrm{mL}\right)$. While hexane extract exhibited both a potent inhibitory effect on VERO cell growth with $\mathrm{IC}_{50}=15.125 \mu \mathrm{g} / \mathrm{mL}$ and a total inhibitory effect on Staphylococcus aureus with inhibition zone $8.5 \mathrm{~mm}$. The high content of polyphenols in A. longa explains their antioxidant, antitumor, and antibacterial activity. Thus, this plant could be a significant source of natural compounds in preventing the development of cancer.
\end{abstract}

Keywords: Aristolochia longa; phenolic content; antioxidant; antibacterial; antitumor.

(C) 2020 by the authors. This article is an open-access article distributed under the terms and conditions of the Creative Commons Attribution (CC BY) license (https://creativecommons.org/licenses/by/4.0/).

\section{Introduction}

Natural products design a new lead of drug discovery because of the presence of bioactive compounds that exhibited fewer side effects. Currently, naturally derived products used in pharmaceutical companies are originated from plants (25\%), microorganisms (13\%), and animals (25\%) and present a promising opportunity to treat different diseases. Nowadays, herbal plants are primary health care, and the worldwide trade market of herbal medicine is annually growing at the rate of 10-15\% [1,2]. Due to its geographical situation and heterogenic climate, Morocco presents a rich flora regroups more than 5200 species of plants, including 900 endemics [3]. 
Aristolochia is a genus that belongs to Aristolochiaceae family that contains about 500 species. This family has been reported in the forest of America, Asia, Africa, Europe, and rarely in other countries [4-6]. In Morocco, Aristolochia longa, known as Bereztem, is a species used in folk medicine to treat different diseases such as cancer, diabetes, asthma, and skin and intestinal affection using a different part of this plant with several forms viz. honey, milk and jus [7-12]. A recent ethnopharmacological study conducted by El Yahyaoui reported that root is the most used part of treating cancer in Morocco [13].

Chemical analysis of the extracts from different parts of $A$. longa revealed the presence of a wide range of bioactive compounds distributed in several phytochemical classes such as flavonoids, terpenoids, alkaloids, and fatty acid. Previous investigations carried out in several essential oils, organic and aqueous extracts of a different part of this plant, showed the presence of aristolochic acid (AA), maaliol, lycopene, limonene, palmitic acid, and $\beta$-caryophyllene [9,11-13]. In addition, several researches reported the pharmacological properties of $A$. longa and their compounds, which elicit pharmacological effects, including antitumoral, antibacterial, antifungal, anti-inflammatory, antidiabetic, antioxidant activities $[9,14,15,17$ 19]. Furthermore, a recent study has evaluated the toxicity effect of this plant in vivo [20]. The aim of this study was devoted to determining phenolic and flavonoid content as well to evaluate the antioxidant, antitumor, and antibacterial activities of the root of $A$. longa from the Moroccan region.

\section{Materials and Methods}

\subsection{Plant material.}

The fresh root of A. longa was harvested in the cities Rabat (September 2014), Morocco. The plant, identified by Professor Kahouadji Azzeddine, Faculty of Sciences Rabat, Morocco, was ground and stored in watertight tubes at room temperature. Voucher specimens have been deposited in the Laboratory of Human Pathologies Biology, Mohammed 5 University, Faculty of Sciences, Rabat, Morocco.

\subsection{Preparation of extract.}

A. longa root extract was obtained by the maceration of the root powder ( $70 \mathrm{~g}$ of powder in $200 \mathrm{~mL}$ of solvent) for three days at room temperature and stirring at 70 revolutions/minute. This powder was successively extracted with hexane, dichloromethane, and methanol using a technique of continuous hot extraction, a Soxhlet extractor. The solvent obtained was then evaporated under reduced pressure to obtain the crude extract. The crude extracts were stored at $-12^{\circ} \mathrm{C}$ until further uses.

\subsection{Qualitative analysis.}

Preliminary qualitative phytochemical analysis was carried out to identify phytochemical constituents of the plant in methanol and aqueous extracts. Following phytochemicals were tested starch, saponosides, tannins, flavonoids, anthocyans, coumarins, sterols, and triterpenes using standard methods, as reported in the literature [21,22]. 


\subsection{Determination of phenolic content.}

\subsubsection{Determination of total phenolic content.}

The assessment of total polyphenols was performed according to the method of Singleton et al. [23] using the Folin-Ciocalteu as a reagent. On this base, the extracts are diluted to a concentration of $1 \mathrm{mg} / \mathrm{mL}$. An amount of $100 \mu \mathrm{L}$ of the diluted extract is placed in test tubes, and $500 \mu \mathrm{L}$ of Folin-Ciocalteu reagent diluted 10 times in distilled water is added. After incubation for $1 \mathrm{~h}$ at room temperature, $2 \mathrm{~mL}$ of sodium carbonate $\left(\mathrm{Na}_{2} \mathrm{CO}_{3}\right)$ to $2 \%$ is added. The tubes are then shacked and placed in the dark for 30 minutes at room temperature. The same steps were followed to establish a reference range ( 0 to $100 \mu \mathrm{g} / \mathrm{mL}$ ) prepared from an aqueous stock solution of gallic acid $(0.5 \mathrm{~g} / \mathrm{L})$. The absorbance is measured using a UV-Visible spectrophotometer at a wavelength of $760 \mathrm{~nm} \mathrm{[24].} \mathrm{The} \mathrm{absorbance} \mathrm{values} \mathrm{of} \mathrm{each}$ concentration enabled us to plot the calibration curve of gallic acid. The results are expressed in $\mathrm{mg}$ of gallic acid equivalents per gram of dry extract (GAE mg/g of dry extract). All manipulations are performed in triplicate.

\subsubsection{Determination of total flavonoids content.}

Flavonoids contents are measured using aluminum trichloride $\left(\mathrm{AlCl}_{3}\right)$ as a reagent. $1 \mathrm{~mL}$ of the extract of $A$. longa is mixed with $1 \mathrm{~mL}$ of the solution of aluminum trichloride (2\%) and $50 \mu \mathrm{L}$ of acetic acid. The tubes are then gently mixed and incubated in the dark for 40 minutes at room temperature. Under the same conditions, a stock solution of quercetin mass concentration $0.2 \mathrm{~g} / \mathrm{L}$ was prepared in methanol. From this stock solution, a standard range of concentrations from 0 to $25 \mathrm{mg} / \mathrm{mL}$ was prepared - the absorbance measured in the same spectrophotometer at a wavelength of $415 \mathrm{~nm}$ [23]. The obtained absorbance values enabled us to plot the calibration curve of quercetin. The results are expressed in $\mathrm{mg}$ of quercetin equivalent per $g$ of dry extract (mg QE/g of dry extract). All manipulations are performed in three trials.

\subsection{Antioxidant activity.}

The antioxidant activity was determined according to the method Kubola and Siriamornpun with some modifications. Briefly, $1.8 \mathrm{~mL}$ of $0.1 \mathrm{mM}$ DPPH solution is prepared in methanol and added into $0.2 \mathrm{~mL}$ tubes containing extract (methanol or ethanol) at increasing concentrations $(0.31 \mathrm{mg} / \mathrm{mL}-10 \mathrm{mg} / \mathrm{mL}$ for $A$. longa extracts) and are placed away from light at room temperature after agitation by a vortex. After $30 \mathrm{~min}$, the absorbance is measured at $517 \mathrm{~nm}$ [25]. Ascorbic acid (vitamin C) was used as positive controls, while the methanol is used as a negative control. The scavenging activity of DPPH radical is calculated using the following formula: $\mathrm{A} \%=(\mathrm{Abs}$ control $-\mathrm{Abs}$ sample $) \times 100 / \mathrm{Abs}$ control $)$

Abs control: Absorbance without antioxidant (containing all reagents except the test sample) Abs sample: absorbance with the test sample.

$\mathrm{IC}_{50}$ is the concentration of the test sample required to reduce $50 \%$ of DPPH radicals. $\mathrm{IC}_{50}$ was graphically calculated by linear regression plots graphs, percentage inhibition as a function of different concentrations of the tested fractions and standards. 


\subsection{Cell viability assays.}

The in vitro cytotoxic effect of the various extracts was evaluated on RD: Embryonal Rhabdomyosarcoma cancerous cell lines (ATCC $\left.\mathrm{N}^{\circ} \mathrm{CCL}-136\right)$, and Vero: Monkey kidney cancerous cell lines (ATCC $\mathrm{N}^{\circ} \mathrm{CCL}-81$ ) which obtained from the National Institute of Health, Rabat-Morocco. PBMC (Peripheral Blood Mononuclear Cell) isolated and purified from human blood was used as a positive control. Cells were grown in Dulbecco's Modified Eagle Medium (DMEM) (GIBCO) supplemented with 10\% heat-inactivated fetal calf serum and $1 \%$ Penicillin-Streptomycin mixture. Cultures were maintained at $37^{\circ} \mathrm{C}$ in $5 \% \mathrm{CO}_{2}$ and $100 \%$ relative humidity atmosphere. The effect of the isolated extracts on cell viability was assessed using the 3-(4,5-dimethylthiazol -2-yl)-2, 5 diphenyltetrazolium bromide (MTT) assay, which measures the metabolic activity of mitochondria [26]. The tests were conducted on 96-well microplate. Before treatment with extracts, $100 \mu \mathrm{L}$ medium DMEM (GIBCO) containing 3$4 \times 106$ cells $/ \mathrm{mL}$ were placed in each well containing DMEM (GIBCO) and cultured at $37^{\circ} \mathrm{C}$ in $5 \% \mathrm{CO}_{2} /$ humidified air for $24 \mathrm{~h}$. After $24 \mathrm{~h}$ incubation and attachment, cells were treated with crude extracts. Exactly from the stock solution $(80 \mathrm{mg} / \mathrm{mL})$, each extracted sample was applied in a series of 6 dilutions (final concentrations ranging from $12.5 \mu \mathrm{g} / \mathrm{mL}$ to $400 \mu \mathrm{g} / \mathrm{mL}$ ) in Dimethyl sulfoxide (DMSO 1\%). Test solution $(100 \mu \mathrm{L})$ was added in decreasing concentrations in duplicate. The microplate was then incubated for $48 \mathrm{~h}$ at $37^{\circ} \mathrm{C}$ in the air condition of $5 \% \mathrm{CO}_{2}$. After, a $20 \mu \mathrm{L}$ MTT solution $(5 \mathrm{mg} / \mathrm{mL}$ ) (SIGMA) was added to the wells containing cells. The cells were incubated for $4-5 \mathrm{~h}$ at $37^{\circ} \mathrm{C}$ in $5 \% \mathrm{CO}_{2}$. Tetrazolium salts are cleaved to formazan dye by a cellular enzyme (only in the viable cells). A solubilization solution (Isopropanol/hydrochloric acid) is added to dissolve the insoluble purple formazan product into a coloration solution. The absorbance was measured at $545 \mathrm{~nm}$, using a microplate reader (Statfax 2100).

\subsection{Antibacterial activity.}

We used agar well diffusion methods to determine the antimicrobial activities of our extracts. Six species of bacteria were studied, 4 species of Gram-positive bacteria and two species of Gram-negative bacteria (Table 1). The test samples were first dissolved in dimethylsulfoxide (1\%) who thus did not affect the microbial growth. Briefly, $8 \mathrm{~mL}$ of medium agar was poured into sterile Petri plates. After solidification, $100 \mu \mathrm{L}$ of fresh cultures of each bacterial (one microorganism per Petri dish) were swabbed on the respective plates. Then, 50 $\mu \mathrm{L}$ of extracts were placed in wells previously punched over the agar plates using sterile Pasteur pipette, at various concentrations $(10 \mathrm{mg} / \mathrm{mL} ; 20 \mathrm{mg} / \mathrm{mL} ; 30 \mathrm{mg} / \mathrm{mL} ; 40 \mathrm{mg} / \mathrm{mL} ; 50 \mathrm{mg} / \mathrm{mL})$. All Petri plates were then incubated at $37^{\circ} \mathrm{C}$ for $24 \mathrm{~h}$. The diameters of inhibition zones were measured in millimeters. Moreover, commercially available antibiotics were used to compare with the antimicrobial activities of our plant extracts on all bacterial species studied. The antibiotic discs of Ampicillin were placed on the surface of the plates. DMSO 1\% was used as a negative control. The plates were incubated at $37^{\circ} \mathrm{C}$ for $24 \mathrm{~h}$, and after incubation, the diameter of the inhibition zones was measured in $\mathrm{mm}$ and recorded [27].

Table 1. Bacterial species used and their origins.

\begin{tabular}{l|l} 
Bacterial species & Origins \\
\hline Escherichia coli & Food Microbiology Laboratory, UCL, Belgium (MBLA) \\
\hline Pseudomonas aeruginosa IH & Rabat Institute of Hygiene \\
\hline Staphylococcus aureus & German Collection of DSM Microorganisms \\
\hline Rhodococcus equi (GK1, GK2, GK3) & Laboratory of Human Pathologies Biology, UM5, Rabat
\end{tabular}




\section{Results and Discussion}

\subsection{Qualitative analysis.}

The phytochemical screening of $A$. longa roots revealed the presence of starch, tannins, flavonoids, coumarins, anthocyans, and the absence of saponins, sterols, and triterpenes (Table 2). These findings showed similarity with the earlier study, which reports that the phytochemical screening of A. longa revealed the presence of flavonoids, and saponins, and the absence of sterols and triterpenes [14]. In 2019, Bouteldja et al. [28] evaluated the phytochemical screening of $A$. longa methanolic extracts from the aerial part found in Algeria. This extract revealed the presence of tannins, and flavonoids while anthocyanins, steroids, and terpenoids were absent.

In addition, several studies reported the phytochemical composition of species in the same genus. Aerial parts of A. indica from India showed the presence of terpenes, saponins, tannins, and flavonoids [29]. In recent studies, Bourhiya et al. [30,31] assessed the phytochemical screening roots from A. baetica, and A. paucinervis and revealed the presence of flavonoids, polyphenols, alkaloids, tannins, and saponins and the absence of anthraquinone, sterols, and terpenes. Despite the part use, the plant localization, the type of extract, the groups, namely sterols, steroids, terpenes, triterpenes, anthocyanins, anthraquinone, were absent in the genus of Aristolochia.

Table 2. Preliminary qualitative phytochemical analysis of $A$. longa methanol and aqueous root extracts.

\begin{tabular}{l|l|l} 
Plants constituents & Methanol extract & Aqueous extract \\
\hline Starch & & ++ \\
\hline Saponosides & & - \\
\hline Tannins & + & + \\
\hline Flavonoids & ++ & \\
\hline Coumarins & + & \\
\hline Anthocyans & + & \\
\hline Sterols & - & \\
\hline $\begin{array}{l}\text { Triterpenes } \\
\quad+++ \text { highly present, }\end{array}$ & -++ moderately present, + : Low, $-:$ absent.
\end{tabular}

\subsection{Phenolic content.}

The contents of total polyphenols have been determined by colorimetric assay using the Folin-Ciocalteu reagent. The results are expressed in $\mathrm{mg}$ GAE/g extract by referring to the previously established calibration curve with gallic acid (polyphenol correlation: $\mathrm{R}^{2}=0.998$ ). Total flavonoids are determined by the trichloride reagent aluminum, and the results are expressed in $\mathrm{mg}$ QE/g extract based on the established calibration curve with quercetin (flavonoid correlation: $\mathrm{R}^{2}=0.985$ ). The results of the polyphenol and flavonoid contents of extracts of $A$. longa are illustrated in Table 3 .

The total phenolic content of various extracts of $A$. longa from root parts was varying widely between 29.54 to $101.41 \mathrm{mg} \mathrm{GAE} / \mathrm{g}$ extract (Table 3). The methanolic extract was demonstrating higher total polyphenols content $(101.41 \pm 0.85 \mathrm{mg} \mathrm{GAE} / \mathrm{g})$ followed by ethanol and hexane extracts, which were $89.41 \pm 4.96 \mathrm{mg} \mathrm{GAE} / \mathrm{g}$, and $76.41 \pm 8.74 \mathrm{mg} \mathrm{GAE} / \mathrm{g}$, respectively. Results of flavonoids' contents show that methanolic extract resulted a high value of another fraction $(54.2 \pm 10.12 \mathrm{mg} \mathrm{QE} / \mathrm{g})$.

The concentration of polyphenols and flavonoids of our extract is widely higher compare to other studies. In a recent study, El Omari et al. [9] reported that the methanolic fraction of A. longa from root contains $24.48 \pm 1.63 \mathrm{mg} \mathrm{GAE} / \mathrm{g}$ of polyphenols and $7.00 \pm 0.61$ 
mg RE (Rutin equivalent)/g of flavonoids. While Djeridane et al. [32] studied A. longa roots and reported a total phenolics and flavonoids content as $1.47 \pm 0.02 \mathrm{mg} \mathrm{GAE} / \mathrm{g}$ and $0.81 \pm 0.02$ $\mathrm{mg} \mathrm{RE/g}$, respectively. Previous studies reported that the methanolic extract from Aristolochia species (A. indica, Aristolochia baetica, and Aristolochia paucinervis, and Aristolochia bodamae) contains a high amount of phenols and flavonoids. However, phenols and flavonoids content vary from different studies [30,33,34]. Several factors may affect their content. Studies have shown that extrinsic factors (such as geographic and climatic factors), genetic factors, but also the degree of maturation of the plant and the storage time, have a strong influence on the content in polyphenols [35-38].

Table 3. Total phenolic and flavonoids content of root extract of A. longa.

\begin{tabular}{l|l|l}
\multicolumn{2}{c}{} & \multicolumn{2}{c}{ A. longa } \\
\cline { 2 - 3 } & Polyphenols (mg of GAE/g of extract) & Flavonoids (mg of QE/g of extract) \\
\hline Dichloromethane extract & $89.41 \pm 4.96$ & $34.02 \pm 1.87$ \\
\hline Methanolic extract & $101.41 \pm 0.85$ & $54.21 \pm 0.17$ \\
\hline Hexanic extract & $76.41 \pm 8.74$ & $29.54 \pm 0.95$
\end{tabular}

GAE: Gallic acid equivalents; QE: Quercetin equivalent

\subsection{Antioxidant activity.}

Antioxidant activity was performed using in vitro DPPH methods. The results are expressed in ascorbic acid equivalents. The DPPH radical scavenging activity of different extract of A. longa at various concentrations are illustrated in Figure 1, and all extracts showed a scavenging activity which increases with samples concentration. A lower value of $\mathrm{IC}_{50}$ indicates greater antioxidant activity. Among the solvent used, methanolic extract was registered a high antioxidant activity, $\mathrm{IC}_{50}=1.32 \mathrm{mg} / \mathrm{mL}$. Hexane and dichloromethane extract of $A$. longa have an $\mathrm{IC}_{50}>5 \mathrm{mg} / \mathrm{mL}$ (Table 4). IC 50 of ascorbic acid was $27.20 \pm 0.17 \mu \mathrm{g} / \mathrm{mL}$. High antioxidant activity of ascorbic acid can be explained by his use as a pure molecule compares to our extract, which contained several molecules.

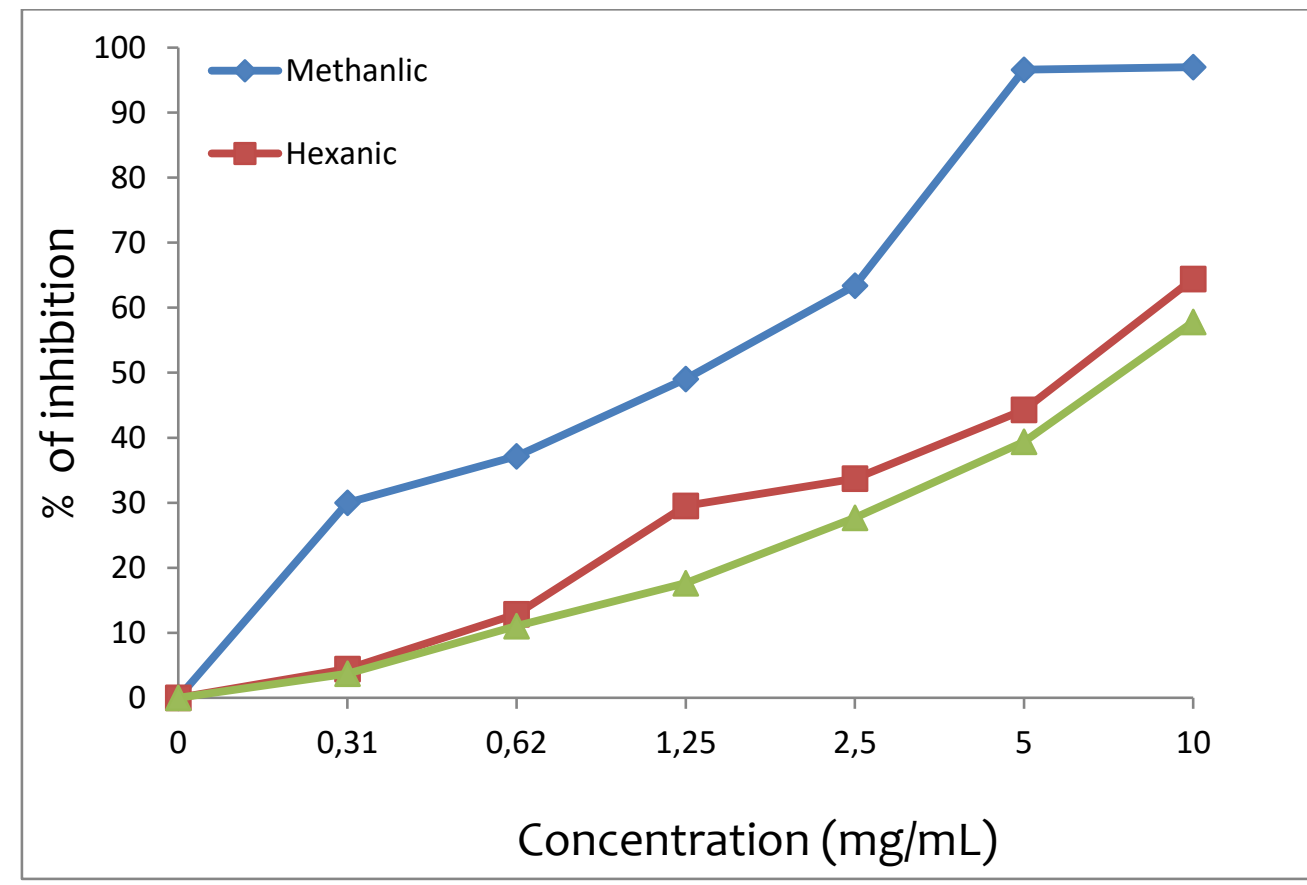

Figure 1. DPPH radical scavenging activity of $A$. longa organic extract. 
Table 4. Free radical (DPPH) scavenging activity of $A$. longa organic extract.

\begin{tabular}{l|l|l} 
& Extracts & IC $_{\text {50 }}(\mathbf{m g} / \mathbf{m L})$ \\
\hline \multirow{3}{*}{ A. longa } & Methanol & 1.32 \\
\cline { 2 - 3 } & Hexane & 6.58 \\
\cline { 2 - 3 } & Dichloromethane & 8.26
\end{tabular}

Numerous studies investigated the ability of organic extract of a different part of $A$. longa to scavenge free radical using DPPH scavenging activity. A recent Moroccan study reported the highest inhibition of $A$. longa root aqueous fraction with $\mathrm{IC}_{50}=125.40 \pm 2.40$ $\mu \mathrm{g} / \mathrm{mL}$ [9]. An in vitro research carried out by Merouani et al. showed that aerial parts methanol extract exhibited the highest dose-dependent reducing DPPH with $\mathrm{IC}_{50}=55.04 \mu \mathrm{g} / \mathrm{mL}$ with no significant ( $\mathrm{p}>0.05$ ) [15]. In Algeria, Djeridane et al. [32] reported an $\mathrm{IC}_{50}=55.04 \pm 0.4 \mu \mathrm{M}$. The antioxidant activity of these extracts is related to the highly important charges of phenolic compounds polyphenols and flavonoids. Indeed, several in vitro and in vivo researches reported the correlation between phenolic compounds and antioxidant effects and also with the synergy effect with other compounds [39-41].

\subsection{Cytotoxicity effects.}

The cytotoxic potential of $A$. longa organic extracts was conducted on two tumor cell lines: RD, and VERO. These lasts were treated with different concentrations of extracts from $15.12 \mu \mathrm{g} / \mathrm{mL}$ to $1000 \mu \mathrm{g} / \mathrm{mL}$. Assay by the MTT assay indicates that extracts revealed different cytotoxic activities towards two cancer cell lines investigated (RD and VERO). The results have been compared to control (PBMC) to compare the antiproliferative effects of extracts. The obtained results are listed in Table 5. In general, a dose-dependent decrease in the survival of the two cancerous cell lines is illustrated in figure 2 and figure 3. Amongst these tested plant extracts, hexane extracts exhibited potent and selective antiproliferative activities against VERO and RD cell lines with the same $\mathrm{IC}_{50}\left(\mathrm{IC}_{50}=15.12 \mu \mathrm{g} / \mathrm{mL}\right)$ (Figure 3, and Figure 2).

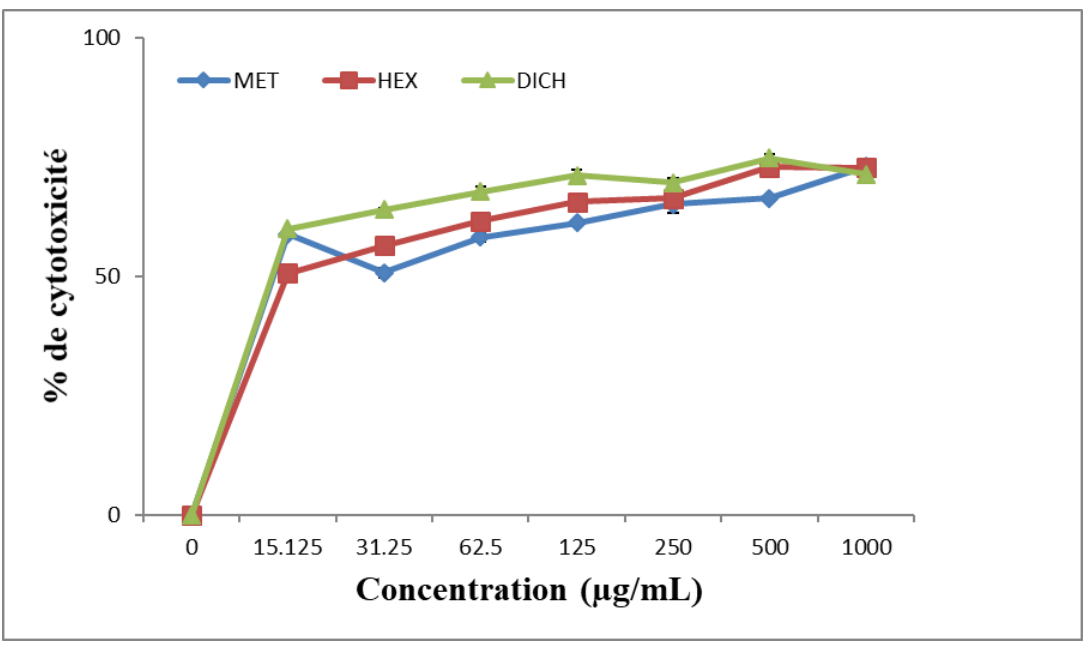

Figure 2. Cytotoxic activity of root extract of $A$. longa against RD cell lines.

At the same time, there is no significant effect of dichloromethane and methanol extracts. The cytotoxic activity of hexane extracts showed low cytotoxicity against normal cells (PBMC) with IC50 values of $62.57 \pm 16.295 \mu \mathrm{g} / \mathrm{mL}$ (Table 5, and Figure 4). In our study, the presence of polyphenols and flavonoids in hexane extracts $(76.41 \pm 8.74 \mathrm{mg}$ of GAE/g, and $29.54 \pm 0.95 \mathrm{mg}$ of QE/g, respectively) may explain the cytotoxic effect on RD and VERO tumor cell lines. Several researches reported the activity of $A$. longa extracts against various 
cancerous cell lines [40,42]. Benarba et al. reported an $\mathrm{IC}_{50}=15.63 \mu \mathrm{g} / \mathrm{mL}$ for $A$. longa aqueous extract against Burkitt's lymphoma BL41 cells [42]. A previous study reported the effect of tuber extracts of this plant on the same cell line used in this study. In our laboratory, the cytotoxic effect of $A$. longa tuber extracts has been studied by Aneb et al. [40]. They screened the cytotoxic effect of hexane and dichloromethane extract, which presented a cytotoxic capacity $\mathrm{IC}_{50}=30 \mu \mathrm{g} / \mathrm{mL}$ and $\mathrm{IC}_{50}=15 \mu \mathrm{g} / \mathrm{mL}$, respectively, on $\mathrm{RD}$ cell lines [40]. The mechanism of action of extracts through which compounds act in their cytotoxic effect is not fully understood. However, the authors suggested that these compounds act thought the membrane disruption, apoptosis pathways, and inactivation of telomerase $[40,43]$.

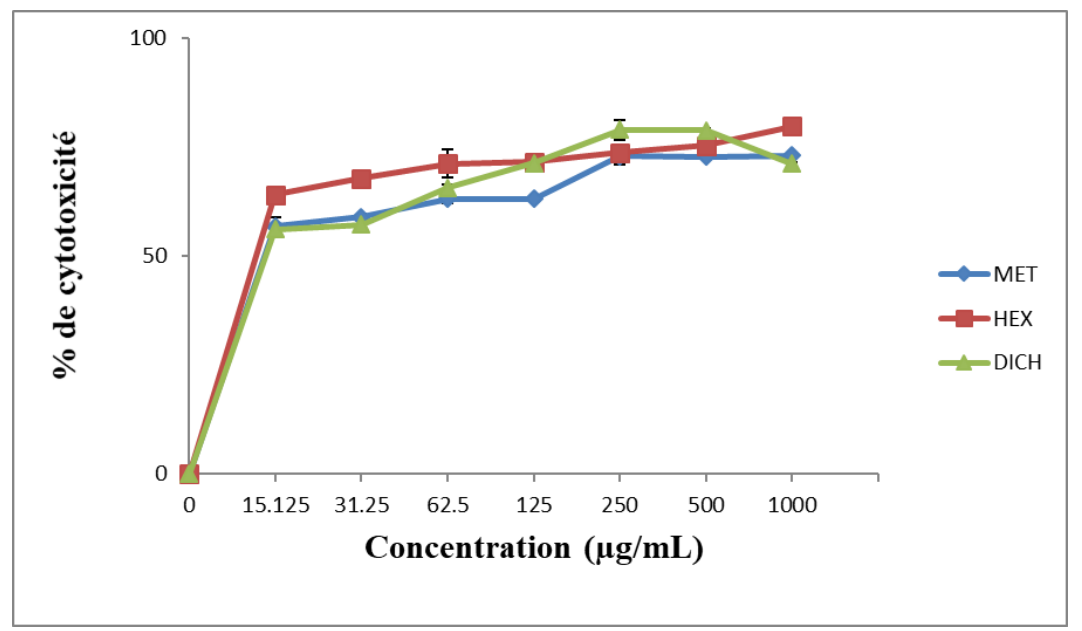

Figure 3. Cytotoxic activity of root extract of $A$. longa against VERO cell lines.

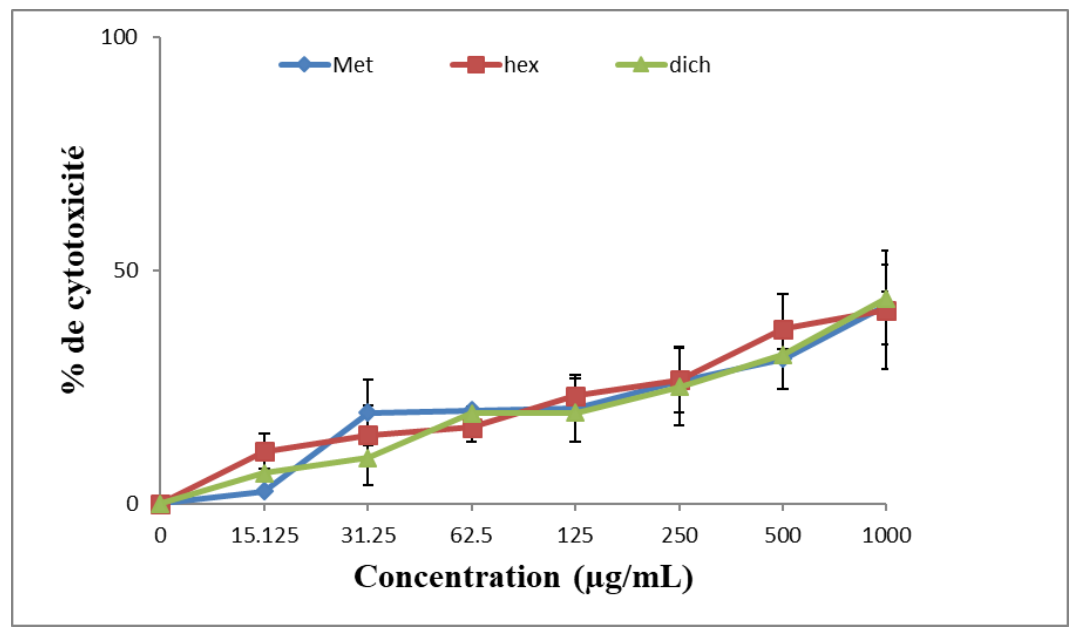

Figure 4. Cytotoxic activity of $A$. longa root extracts against PBMC cell lines.

Table 5. Inhibition concentration ( $\mathrm{IC}_{50}$ in $\mu \mathrm{g} / \mathrm{mL}$ ) values from $A$. longa towards $\mathrm{RD}, \mathrm{VERO}$ cancerous cell lines, and PBMC (control) as determined by the MTT assay.

\begin{tabular}{|c|c|c|c|c|}
\hline & \multicolumn{3}{|l|}{ A. longa } \\
\hline & & Hexane & Dichloromethane & Methanol \\
\hline \multirow{3}{*}{$\mathrm{IC}_{50}(\mu \mathrm{g} / \mathrm{ml})$} & RD & $15.12 \pm 66.32$ & $125.43 \pm 71.17$ & $62.5 \pm 61.24$ \\
\hline & PBMC & $62.57 \pm 16.295$ & $14.16 \pm 6.48$ & $31.25 \pm 09.765$ \\
\hline & VERO & $15.125 \pm 64.01$ & $31.25 \pm 57.17$ & $125.3 \pm 63.13$ \\
\hline
\end{tabular}

\subsection{Antibacterial activity.}

This study evaluated the antibacterial activity of A. longa hexane, dichloromethane, and methanolic extracts on Gram-positive and Gram-negative strains. The results of agar well diffusion methods showed that each extract has a different degree of growth inhibition (Table 
6). At $10 \mathrm{mg} / \mathrm{mL}, S$. aureus showed a high sensitivity against hexane extract with diameters inhibition $8.5 \mathrm{~mm}$. The effect of three bacterial strains of genus Rhodococcus were tested. At $50 \mathrm{mg} / \mathrm{ml}$, hexane and dichloromethane extracts were found to possess a higher antibacterial activity against Rhodococcus sp GK1 with a diameter of inhibition $1.55 \mathrm{~mm}$ and $1.9 \mathrm{~mm}$, respectively. While for Gram-, a lower activity inhibition effect was observed for $E$. coli, and P. aeruginosa.

Previous studies reported that $A$. longa has a significant in vitro antibacterial activity against Rhodococcus sp, $S$. aureus, E. coli, and $P$. aeruginosa [15,40]. Aneb et al. reported the highest inhibition activity of hexane and methanolic extract against $R$. equi $(25 \mathrm{~mm}, 12 \mathrm{~mm}$, respectively). While in Algeria, the fruit methanolic extract and aerial part aqueous extract showed the highest inhibitory effects against $S$. aureus with inhibition zone diameter of $22 \mathrm{~mm}$, and $20 \mathrm{~mm}$, respectively [15]. The variability of these results was influenced by, the solvent used, the extract used, the extraction methods as well as bioactive compounds [15,40]. These last act in targeting different mechanisms pathways such as cell membrane and the cytoplasm and also by modifying cell morphology and gene expression [44].

Table 6. Antibacterial activity of A. longa extract against Rhodococcus sp., S. aureus, E. coli, and P. aeruginosa was determined by agar well diffusion $(\varnothing \mathrm{mm})$.

\begin{tabular}{|c|c|c|c|c|c|c|c|c|}
\hline & \multirow[t]{2}{*}{ Extract } & \multirow{2}{*}{$\begin{array}{l}\text { Concentrations/ } \\
\text { species }\end{array}$} & \multicolumn{6}{|c|}{ Zone of inhibition ( $\varnothing \mathbf{~ m m})$} \\
\hline & & & $\begin{array}{l}\text { GK1 } \\
+ \\
\end{array}$ & GK2 & GK3 & $\begin{array}{l}\text { S. aureus } \\
+\end{array}$ & $\begin{array}{l}\text { E. coli } \\
-\end{array}$ & $\begin{array}{l}\text { P. aeruginosa } \\
\text { - }\end{array}$ \\
\hline \multirow[t]{18}{*}{ A. longa } & \multirow[t]{5}{*}{$\mathrm{DICH}$} & $10 \mathrm{mg} / \mathrm{mL}$ & 0 & 0 & 0 & 1.05 & 1 & 0 \\
\hline & & $20 \mathrm{mg} / \mathrm{mL}$ & 0 & 0.55 & 0 & 0.95 & 0.8 & 0.23 \\
\hline & & $30 \mathrm{mg} / \mathrm{mL}$ & 1 & 0.6 & 0 & 1.2 & 0 & 0.26 \\
\hline & & $40 \mathrm{mg} / \mathrm{mL}$ & 0.35 & 0.45 & 0 & 0.85 & 1.1 & 0 \\
\hline & & $50 \mathrm{mg} / \mathrm{mL}$ & 1.55 & 0.85 & 0 & 0.55 & 0 & 0 \\
\hline & \multirow[t]{8}{*}{ HEX } & $10 \mathrm{mg} / \mathrm{mL}$ & 0 & 1.3 & 1.45 & 8.5 & 0.6 & 0 \\
\hline & & $20 \mathrm{mg} / \mathrm{mL}$ & 0.8 & 1.45 & 1.15 & 5 & 1.15 & 0.36 \\
\hline & & $30 \mathrm{mg} / \mathrm{mL}$ & 0 & 1.1 & 0 & 6 & 1.1 & 0.5 \\
\hline & & $40 \mathrm{mg} / \mathrm{mL}$ & 1.65 & 1.35 & 1.8 & 5 & 0.75 & 0 \\
\hline & & $50 \mathrm{mg} / \mathrm{mL}$ & 1.9 & 0 & 1.35 & 7 & 0 & 0 \\
\hline & & $60 \mathrm{mg} / \mathrm{mL}$ & 0 & 1.25 & 0 & - & - & 0.98 \\
\hline & & $70 \mathrm{mg} / \mathrm{mL}$ & 0 & 0 & 1.45 & - & - & 0.55 \\
\hline & & $80 \mathrm{mg} / \mathrm{mL}$ & 0 & 0 & 1.15 & - & - & 0 \\
\hline & \multirow[t]{5}{*}{ METH } & $10 \mathrm{mg} / \mathrm{mL}$ & 1.1 & 1.25 & 1 & 0.15 & 1 & 0.3 \\
\hline & & $20 \mathrm{mg} / \mathrm{mL}$ & 1.25 & 1.05 & 0.75 & 1 & 0.8 & 0.23 \\
\hline & & $30 \mathrm{mg} / \mathrm{mL}$ & 0.3 & 1.25 & 1.2 & 0.8 & 0 & 0 \\
\hline & & $40 \mathrm{mg} / \mathrm{mL}$ & 0.6 & 0 & 0.85 & 0.8 & 1.1 & 0 \\
\hline & & $50 \mathrm{mg} / \mathrm{mL}$ & 0.75 & 0 & 0 & 0.65 & 0 & 0 \\
\hline \multicolumn{2}{|c|}{ Amoxycillin } & $50 \mathrm{mg} / \mathrm{mL}$ & 6 & 6 & 7 & 8 & 6.5 & 7 \\
\hline \multicolumn{2}{|c|}{ DMSO } & $1000 \mathrm{mg} / \mathrm{mL}$ & 7 & 6 & 7 & 7.5 & 6 & 8 \\
\hline
\end{tabular}

Tests were carried out in 3. Bacterial cells were incubated with plant extracts at $37^{\circ} \mathrm{C}$ for $24 \mathrm{~h}$. Data are expressed as means of inhibition zone in $\mathrm{mm} \pm \mathrm{SD}$ of 3 independent experiments.

(DICH: dichloromethane, HEX: hexane, METH: methanol)

\section{Conclusions}

The present study showed that methanolic extract, rich in polyphenols and flavonoids, showed remarkable antioxidant activity. However, hexane extract exhibited the highest antibacterial activity against $R$. equi and $S$. aureus, and exhibited the highest anticancer activity against VERO cancerous cell lines. These results justify the use of this plant by the Moroccan population as a beneficial folk plant in the treatment of cancer and as a source of natural compounds in the pharmaceutical industry. Therefore, further research should be conducted to separate these phenols compounds, elucidate their structure, and identify and isolate the 
bioactive compounds. These researches are necessary to fully understand the antibacterial and antitumor mechanism of $A$. longa.

\section{Funding}

This research received no external funding.

\section{Acknowledgments}

This research has no acknowledgment.

\section{Conflicts of Interest}

The authors declare no conflict of interest.

\section{References}

1. Calixto, J.B. The role of natural products in modern drug discovery. An Acad Bras Cienc 2019, 91, https://doi.org/10.1590/0001-3765201920190105.

2. Patra, J.; Shukla, A.; Das, G. Advances in Pharmaceutical Biotechnology. Publisher: Springer, Singapore, 2020; pp. 3-13, https://doi.org/10.1007/978-981-15-2195-9.

3. El Hachlafi, N.; Chebat, A.; Bencheikh, R.S.; Fikri-Benbrahim, K. Ethnopharmacological study of medicinal plants used for chronic diseases treatment in Rabat-Sale-Kenitra region (Morocco). Ethnobot Res Appl 2020, 20, http://dx.doi.org/10.32859/era.20.2.1-23.

4. Heinricha, M.; Chan, J.; Wanke, S.; Neinhuis, C.; Simmonds, M.S. Local uses of Aristolochia species and content of nephrotoxic aristolochic acid 1 and 2-A global assessment based on bibliographic sources. $J$ Ethnopharmacol 2009, 125, 108-144, https://doi.org/10.1016/j.jep.2009.05.028.

5. Dey, A.; De, J.N. Aristolochia indica L.: A Review. Asian J Plant Sci 2011, 10, 108-116, https://doi.org/10.3923/ajps.2011.108.116.

6. González, F.; Pabón-Mora, N. Sinopsis actualizada de Aristolochia (Aristolochiaceae, Piperales) en Panamá. Acta Bot Mex 2018, 122, 109-140, http://dx.doi.org/10.21829/abm122.2018.1249.

7. Benarba, B. Medicinal plants used by traditional healers from South-West Algeria: An ethnobotanical study. J Intercul Ethnopharmacol 2016, 5, 320-330, https://doi.org/10.5455/jice.20160814115725.

8. Dhouioui, M.; Boulilaa, A.; Chaabanea, H.; Zina, M.S.; Casabianca, H. Seasonal changes in essential oil composition of Aristolochia longa L ssp paucinervis Batt (Aristolochiaceae) roots and its antimicrobial activity. Ind Crops Prod 2016, 83, 301-306, https://doi.org/10.1016/j.indcrop.2016.01.025.

9. $\quad$ El Omari, N.; Sayah, K.; Fettach, S.; El Blidi, O.; Bouyahya, A.; Fouzia, M.E.A.; Kamal, R.; Barkiyou M. Evaluation of in vitro antioxidant and antidiabetic activities of Aristolochia longa extracts. eCAM 2019, 2019, https://doi.org/10.1155/2019/7384735.

10. Najem, M.; Belaidi, R.; Slimani, I.; Bouiamrine, E.H.; Jamal Ibijbijen, J.; Nassiri, L. Pharmacopée traditionnelle de la région de Zerhoun - Maroc - : connaissances ancestrales et risques de toxicité. Int J Biol Chem Sci 2018, 12, 2797-2807, https://dx.doi.org/10.4314/ijbcs.v12i6.25.

11. Touiti, N.; Houssaini, T.S.; Iken, I.; Benslimane, A.; Achour, S. Prevalence of herbal medicine use among patients with kidney disease: A cross-sectional study from Morocco. Nephrol ther 2020, 16, 43-49, https://doi.org/10.1016/j.nephro.2019.01.007.

12. Zakariya, I.; Ifezouane, J.; Addaoui, A.; Skalli, S.; Bouslimane, Y. Evaluation of the therapeutic and toxicological knowledge of herbalists on the most notified plants in the poison control and pharmacovigilance center of Morocco. J Pharmacognosy Phytother 2018, 10, 126-132, https://doi.org/10.5897/JPP2018.0507.

13. El Yahyaoui El idrissi, A.; Talbaoui, A.; Bouyahya, A.; Khouchlaa, A.; Bakri, Y.; Tijane, M. Ethnobotanical study on the Bereztem Plant (Aristolochia longa) used in the treatment of some diseases in the cities of Rabat, Sale and Temara (Morocco). JMES 2018, 9, 1914-1921.

14. Merouani, N.; Belhattab, R.; Sahli, F. Evaluation of the biological activity of Aristolochia longa L. Extracts. IJPSR 2017, 8, 1978-1992, https://doi.org/10.13040/IJPSR.0975-8232.8(5).1978-92.

15. Dhouioui, M.; Boulila, A.; Jemli, M.; Schiets, F.; Casabianca, H.; Zina, M.S. Fatty acids composition and antibacterial activity of Aristolochia longa L. and Bryonia diö̈ca Jacq. Growing wild in Tunisia. J Oleo Sci 2016, 65, 655-661, https://doi.org/10.5650/jos.ess16001.

16. Benarba, B.; Pandiella, A.; Elmallah, A. Anticancer activity, phytochemical screening and acute toxicity evaluation of an aqueous extract of Aristolochia longa L. Int J Pharm Phytopharm Res 2016, 6, 20-26. 
17. Benarba, B.; Meddah, B. Ethnobotanical study, antifungal activity, phytochemical screening and total phenolic content of Algerian Aristolochia longa. J Inter Ethnopharmacol 2014, 3, 150-154, https://doi.org/10.5455/jice.20140826030222.

18. Derouiche, S.; Zeghib, K.; Gharbi S.; Khelef, Y. Protective effects of Aristolochia longa and Aquilaria malaccensis against lead-induced oxidative stress in rat cerebrum. Asian J Pharm Sci 2019, 9, 57-63, https://doi.org/10.5958/2231-5659.2019.00010.9.

19. Benzakour, G.; Amrani, M.; Oudghiri, M. A Histopathological analyses of in vivo antitumor effect of an aqueous extract of Aristolochia longa used in cancer treatment in traditional medicine in Morocco. Int $J$ Plant Res 2012, 2, 31-35, https://doi.org/10.5923/j.plant.20120202.06.

20. Merouani, N.; Belhattab, R. Acute toxicity of Aristolochia longa L. of aqueous extract in mice. JDDT 2020, 10, 4-0, https://doi.org/10.22270/jddt.v10i3.4055.

21. Andersen, O.M.; Markhan, K.R. Flavnoids: chemistry, biochemistry and applications. Publisher: CRS press, Taylor and Francis group, Boca Raton, 2006; https://doi.org/10.1021/np068246q.

22. Bruneton, J. Pharmacognosy, phytochemistry, medicinal plants. $4^{\text {th }}$ eds. Publisher: Laviosier Publishing, Paris, 2009.

23. Borgi, W.; Chouchane, N. Anti-inflammatory activity of saponosides and flavonoids of the root bark of Zizyphus lotus L] Rev Régions Arides 2007, 1, 283-286, https://doi.org/10.1016/j.sajb.2008.01.009.

24. Singleton, V.; Orthofer, R.; Lamuela-Raventos, R.A. Analysis of total phenols and other oxidation substrates and antioxidants by means of Folin-Ciocalteu reagent. Methods Enzymol 1999, 299, 152-175, https://doi.org/10.1016/S0076-6879(99)99017-1.

25. Hannache, B.; Bazin, D.; Boutefnouchet, A.; Daudon, M. Effect of plant extracts on the in vitro dissolution of cystine stones: A study at the mesoscopic scale. Prog Urol 2012, 22, 577-582, https://doi.org/10.1016/j.purol.2012.06.001.

26. Mosmann, T. Rapid colorometric assay for cellular growth and survival: Application to proliferation and cytotoxicity assays. J Immuno Methods 1983, 65, 55-63, https://doi.org/10.1016/0022-1759(83)90303-4.

27. Daniyan, S.Y.; Mahammad, H.B. Evaluation of the antifungal activities and phytochemical properties of extracts of Tamaridus indica against some diseases causing bacteria. Afri J Biotec 2008, 7, 2451-2453.

28. Bouteldja, R.; Doucene, R.; Bouzid, R.; Moulay, M.; Aggad, H. Biological activity of Aristolochia longa L. against some pathogenic bacteria and phytochemical screening. Facultatea de Medicină Veterinară, Timisoara 2019, 52, 23-30.

29. Subramaniyan, V.; Saravanan, R.; Baskaran, D.; Ramalalingam, S. In vitro free radical scavenging and anticancer potential of Aristolochia indica L. against MCF-7 cell line. Int J Pharm Pharm Sci 2015, 7, 392396.

30. Bourhia, M.; Laasri, F.E.; Moussa, S.I.; Ullah, R.; Bari, A.; Saeed Ali, S.; Kaoutar, A.; Haj Said, A.A.; El Mzibri, M.; Said, G.; Khlil, N.;Benbacer, L. Phytochemistry, Antioxidant Activity, Antiproliferative Effect, and Acute Toxicity Testing of Two Moroccan Aristolochia Species. eCAM 2019, 2019, https://doi.org/10.1155/2019/9710876.

31. Bourhia, M.; Ait Haj Said, A.; Chaanoun, A.; El Gueddari, F.; Naamane, A.; Benbacer, L.; Khlil, N. Phytochemical screening and toxicological study of Aristolochia baetica Linn roots: Histopathological and biochemical evidence. J Toxicol 2019, 2019, https://doi.org/10.1155/2019/8203832.

32. Djeridane, A.; Yousfi, M.; Nadjemi, B.; Maamri, S.; Djireb, F.; Stocker, P. Phenolic extracts from various Algerian plants as strong inhibitors of porcine liver carboxylesterase. J Enzym Inhib Med Ch 2006, 21, 719726, https://doi.org/10.1080/14756360600810399.

33. Sivaraj, D.; Shanmugam, S.; Rajan, M.; Sasidharan, S.P.; Sathyanarayanan, S.; Muniyandi, K.; Thangaraj, P.; de Souza Araújo, A.A. Evaluation of Aristolochia indica L. and Piper nigrum L. methanol extract against centipede Scolopendra moristans L. using Wistar albino rats and screening of bioactive compounds by high pressure liquid chromatography: a polyherbal formulation. Biomed Pharmacother 2018, 97, 1603-1612, https://doi.org/10.1016/j.biopha.2017.11.114.

34. Ozen, T.; Bora, N.; Yenigun, S.; Korkmaz, H. An investigation of chemical content, enzyme inhibitory propert, antioxidant and antibacterial activity of Aristolochia bodamae Dingler (develiotu) (Aristolochiaceae) root extracts from Samsun, Turkey. Flavour Fragr J 2019, 00, 1-14, https://doi.org/10.1002/ffj.3559.

35. Generalić, I.; Ljubenkov, I.; Možina, S.S, Abramović, H.; Šimat, V.; Katalinić, A.; Novak, T.; Skroza, D. Abiotic factors during a one-year vegetation period affect sage phenolic metabolites, antioxidants and antimicrobials. Ind Crops Prod 2019, 141, https://doi.org/10.1016/j.indcrop.2019.111741.

36. Zhang, C.; Yang, D.; Liang, Z.; Liu, J.; Yan, K.; Zhu, Y, Yang, S. Climatic factors control the geospatial distribution of active ingredients in Salvia miltiorrhiza Bunge in China. Sci Rep 2019, 9, https://doi.org/10.1038/s41598-018-36729-x.

37. Boudieb, K.; Ait Slimane-Ait Kaki, S.; Amellal-Chibane, H. Effect of maturation degree on the fixed oil chemical composition, phenolic compounds, mineral nutrients and antioxidant properties of Pistacia lentiscus L. fruits. Not Bot Horti Agrobo 2019, 47, 836-847, https://doi.org/10.15835/nbha47311534. 
38. Mashabela, M.; Mahajan, P.V.; Sivakumar, D. Influence of different types of modified atmosphere packaging films and storage time on quality and bioactive compounds in fresh-cut cauliflower. Food Packag Shelf Life 2019, 22, https://doi.org/10.1016/j.fpsl.2019.100374.

39. Saad, F.; Mrabti, H.N.; Sayah, K.; Bouyahya, A.; Salhi, N.; Cherrah, Y.; El Abbes, F.M. Phenolic content, acute toxicity of Ajuga iva extracts and assessment of their antioxidant and carbohydrate digestive enzyme inhibitory effects. S Afr J Bot 2019, 125, 381-385, https://doi.org/10.1016/j.sajb.2019.08.010.

40. Aneb, M.; Talbaoui, A.; Bouyahya, A.; EL Boury, H.; Amzazi, S.; Benjouad, A.; Dakka N.; Bakri, Y. In vitro cytotoxic effects and antibacterial activity of Moroccan medicinal plants Aristolochia longa and Lavandula multifida. EJMP 2016, 16, 1-13, https://doi.org/10.9734/EJMP/2016/28534.

41. Bouyahya, A.; Dakka, N.; Talbaoui, A.; Et-Touys, A.; El-Boury, H.; Abrini, J.; Bakri, Y. Correlation between phenological changes, chemical composition and biological activities of the essential oil from Moroccan endemic Oregano (Origanum compactum Benth). Ind Crop Prod 2017, 108, 729-37, https://doi.org/10.1016/j.indcrop.2017.07.033.

42. Benarba, B.; Ambroise, G.; Aoues, A.; Meddah, B.; Vazquez, A. Aristolochia longa aqueous extract triggers the mitochondrial pathway of apoptosis in BL41 burkitt's lymphoma cells. IJGP 2012, 6, 45-49.

43. Guaouguaou, F.Z.; Alien Ahl Bebaha, M.; Taghzouti, K.; Bouyahya, A.; Bakri, Y.; Dakka, N.; Es-Safi, N.E. Cytotoxicological investigation of the essential oil and the extracts of Cotula cinerea and Salvia verbenaca from Morocco. BioMed Reas Inter 2018, 2018, https://doi.org/10.1155/2018/7163961.

44. Bouyahya, A.; Bakri, Y.; Et-Touys, A.; Talbaoui A.; Khouchlaa, A.; Charfi, S.; Abrini, J.; Dakka, N. Resistance to antibiotics and mechanisms of action of essential oils against bacteria. Phytothérapie 2017, 16, 173-183, https://doi.org/10.1007/s10298-017-1118-z. 